\title{
Occurrence and evolutionary inferences about Kranz anatomy in Cyperaceae (Poales)
}

\author{
SHIRLEY MARTINS ${ }^{1}$, MARCCUS ALVES ${ }^{2}$ and VERA L. SCATENA ${ }^{3}$ \\ ${ }^{1}$ Centro de Ciências Biológicas e da Saúde, Laboratório de Botânica, Universidade Estadual do Oeste do \\ Paraná, UNIOESTE, Rua Universitária, 2069, Jardim Universitário, 85819-110 Cascavel, PR, Brasil \\ ${ }^{2}$ Centro de Ciências Biológicas, Departamento de Botânica, Laboratório de Morfotaxonomia Vegetal, Universidade \\ Federal de Pernambuco, UFPE, Rua Prof. Moraes Rego, s/n, Cidade Universitária, 50670-901 Recife, PE, Brasil \\ ${ }^{3}$ Instituto de Biociências, Departamento de Botânica, Laboratório de Anatomia Vegetal, Universidade \\ Estadual Paulista, UNESP, Avenida 24A, 1515, Bela Vista, 13506-900 Rio Claro, SP, Brasil
}

Manuscript received on March 5, 2015; accepted for publication on May 13, 2015

\begin{abstract}
Cyperaceae is an angiosperm family with the greatest diversity of species with Kranz anatomy. Four different types of Kranz anatomy (chlorocyperoid, eleocharoid, fimbristyloid and rhynchosporoid) have been described for this angiosperm family, and the occurrence and structural characteristics of these types are important to trace evolutionary hypotheses. The purpose of this study was to examine the available data on Cyperaceae Kranz anatomy, emphasizing taxonomy, geographic distribution, habitat and anatomy, to infer the potential origin of the Kranz anatomy in this family. The results showed that the four types of Kranz anatomy (associated with $\mathrm{C}_{4}$ photosynthesis) in Cyperaceae emerged numerous times in unrelated phylogenetic groups. However, the convergence of these anatomical types, except rhynchosporoid, was observed in certain groups. Thus, the diverse origin of these species might result from different environmental pressures that promote photorespiration. Greater variation in occurrence of Kranz anatomy and anatomical types was observed in Eleocharis, whose emergence of the $\mathrm{C}_{4}$ pathway was recent compared with other genera in the family, and the species of this genus are located in aquatic environments.
\end{abstract}

Key words: anatomy, ultrastructure, taxonomy, phylogeny, Cyperaceae.

\section{INTRODUCTION}

The Kranz anatomy represents a structural modification of photosynthetic tissues, generally two distinct concentric layers of chlorenchyma cells, associated with $\mathrm{C}_{4}$ metabolism, the main function in plants with suppressed photorespiration, induced through decreased levels of $\mathrm{CO}_{2}$ and

Correspondence to: Shirley Martins

E-mail: shirley_botany@yahoo.com.br increased levels of $\mathrm{O}_{2}$ (Sage 2004, Lundgren et al. 2014). Several factors, such as water stress, high temperature and lightness, and the salinity and high density of plants, influence the reduction of $\mathrm{CO}_{2}$ (Sage et al. 2012).

The structural modification (Kranz anatomy) was initially reported in Cyperaceae species (Haberlandt 1914). Since then, several studies using different approaches have examined the Kranz structure and the $\mathrm{C}_{4}$ pathway in this family (e.g. 
Carolin et al. 1977, Takeda et al. 1985, Bruhl et al. 1987, Ueno and Samejina 1989, Bruhl 1995, Bruhl and Perry 1995, Soros and Dengler 2001, Martins and Alves 2009, Martins and Scatena 2011). The Kranz structure varies in the Cyperaceae family, and four anatomical types have been described: chlorocyperoid, eleocharoid, fimbristyloid and rhynchosporoid. These types anatomically differ in the number and continuity of the vascular bundle sheath and in the presence of chloroplasts in the bundle sheath (Carolin et al. 1977, Soros and Dengler 2001, Martins and Scatena 2011).

Representatives of the Cyperaceae family with Kranz anatomy are restricted to four of the 13 tribes of the Cyperoideae subfamily: Abildgaardieae, Cypereae, Eleocharideae and Rhynchosporeae (Goetghebeur 1998). Among these, only Abildgaardieae and Eleocharideae are closely related in phylogenetic studies (Ghamkhar et al. 2007, Muasya et al. 2008). The Kranz Cypereae species present a Kranz anatomy of the chlorocyperoid type, while the Abildgaardieae species present a Kranz anatomy of the fimbristyloid type (Bruhl and Wilson 2007). Chlorocyperoid, eleocharoid and fimbristyloid types have been described in the Eleocharideae tribe (Murphy et al. 2007, Martins and Scatena 2015), and chlorocyperoid and rhynchosporoid types have been reported in Rhynchosporeae (Martins and Scatena 2011, Ueno 2013).

Therefore, it has been suggested that the origin of Kranz anatomy emerged four times in Cyperaceae, one type in each tribe (Soros and Bruhl 2000). In subsequent studies using molecular markers, five potential appearances of Kranz anatomy were reported: two types in Eleocharideae and one type in each of the remaining Kranz tribes (Besnard et al. 2009). Phylogenetic studies of Abildgaardieae (Ghamkhar et al. 2007) and Eleocharideae (Roalson et al. 2010) indicated multiple origins of $\mathrm{C}_{4}$ photosynthesis.
The variations of Kranz anatomy observed in this family have generated important taxonomic, ecological and evolutive interpretations. Therefore, the aim of the present study was to review taxonomic, ecological, structural and phylogenetic data associated with the structural analyses performed with Cyperaceae species of the four Kranz types (Martins and Scatena 2011, Martins and Scatena 2015, Martins et al. 2015) to develop potential hypotheses concerning the origins of these plants.

\section{MATERIALS AND METHODS}

The species used to illustrate anatomical and ultrastructural features are listed in Table I. The voucher materials were deposited at the Herbarium of the Department of Botany, Universidade Estadual Paulista (HRCB). The data collected here added to the literature are given in Table II.

To anatomically illustrate the different Kranz types, portions of at least three fully expanded leaf blade or scapes were fixed in FAA 50 and stored in 70\% ethanol (Johansen 1940) and subsequently dehydrated in an ethyl alcohol series and embedded in Historesin (Leica Historesin Embedding Kit, Nussloch, Germany) (Feder and O'Brien 1968). Transverse sections of the mid-region were obtained using a microtome, and the sections were stained with periodic acid-Schiff's reagent and toluidine blue (Feder and O'Brien 1968) and mounted in Entellan (Merck Darmstadt, Germany). The images were obtained using Leica DFC 290 digital camera on a Leica DM LB microscope using IM50 software.

To illustrate the ultrastructural features of the four Kranz types, samples from the mid-region of at least three fully expanded leaf blades or scapes were fixed in $2.5 \%$ glutaraldehyde solution in $0.1 \mathrm{M}$ phosphate buffer, $\mathrm{pH} 7.3$, for $24 \mathrm{~h}$ at $5^{\circ} \mathrm{C}$, post-fixed with $1 \%$ osmium tetroxide in the same buffer for $1 \mathrm{~h}$ at $25^{\circ} \mathrm{C}$, dehydrated with an acetone 
series and embedded in Araldite resin (Machado and Rodrigues 2004). Ultrathin transverse sections were obtained using a Diatome diamond knife, and the sections were subsequently stained with uranyl acetate and lead citrate (Reynolds 1963). The samples were examined using a Philips EM 301 transmission electron microscope (MET).

To illustrate the occurrence of the Kranz anatomical types in Cyperaceae, these data were plotted onto cladograms from previously published phylogenetic analyses for each tribe: Abildgaardieae (Ghamkhar et al. 2007), Cypereae (Muasya et al. 2009), Eleocharideae (Roalson et al. 2010) and Rhynchosporeae (Thomas et al. 2008).

\section{RESULTS}

Abildgaardieae tribe - This tribe has six genera with Kranz anatomy, Abildgaardia, Bulbostylis, Crosslandia, Fimbristylis, Nelmesia and Nemum (Tab. II), and two non-Kranz $\left(\mathrm{C}_{3}\right)$ species,
Abildgaardia hygrophila and Fimbristylis variegata. This tribe is non-monophyletic, and representatives of the non-Kranz Arthrostylideae tribe emerge as the sister group of the clade Fimbristylis-Abildgaardia-Crosslandia (Fig. 1e). The Kranz taxa of Abildgaardieae possess the fimbristyloid type, characterized by vascular bundles surrounded by three sheaths, an outer sheath (Os), a continuous middle sheath (Ms), and a discontinuous inner sheath (Is) in the major bundles, interrupted by only one or two metaxylem vessels (Fig. 1a-b). The outer bundle sheath originates from the ground meristem, while the middle and inner sheaths develop from the procambium. The chloroplasts in the outer-sheath cells present well-developed grana, similar to the mesophyll cells. The middle-sheath cells do not show chloroplasts, and the inner-sheath cells show centrifugal chloroplasts without grana (Fig. 1c) and with convoluted and parallel thylakoids (Fig. 1d).

TABLE I

Cyperaceae species used to illustrated the anatomical and ultrastructural features with Kranz types and vouchers, respectively.

\begin{tabular}{ccc}
\hline Tribes and species & Kranz anatomical type & Voucher \\
\hline Abildgaardieae & fimbristyloid & S. Martins 329 \\
Bulbostylis conifera L. & fimbristyloid & S. Martins 408 \\
Bulbostylis scabra (J. Presl. \& C. Presl.) C.B. Clarke & fimbristyloid & V.L. Scatena 343 \\
Fimbristylis autumnalis L. & fimbristyloid & V.L. Scatena 344 \\
Fimbristylis complanata (Retz.) Link & fimbristyloid & S. Martins 398 \\
Fimbristylis dichotoma (L.) Vahl & & \\
Cypereae & chlorocyperoid & S. Martins 228 \\
Cyperus compressus Jacq. & chlorocyperoid & S. Martins 330 \\
Cyperus ligularis L. & chlorocyperoid & S. Martins 226 \\
Cyperus maritimus Poir. & chlorocyperoid & S. Martins 288 \\
Kyllinga brevifolia Rottb. & chlorocyperoid & S. Martins 327 \\
Pycreus flavescens (L.) Rchb. & & \\
Eleocharideae & eleocharoid & S. Martins 405 \\
Eleocharis minima Kunth & & \\
Rhynchosporeae & chlorocyperoid & S. Martins 313 \\
Rhynchospora barbata (Vahl) Kunth & rhynchosporoid & S. Martins 305 \\
Rhynchospora globosa Lindl. & rhynchosporoid & S. Martins 302 \\
\hline
\end{tabular}


TABLE II

Cyperaceae genera with Kranz anatomy $\left(C_{4}\right.$ photosynthesis), detach to taxonomical classification, Kranz anatomical types, biochemical subtypes, habitat and distribution $(\mathrm{K}-\mathrm{C}=$ chlorocyperoid; $\mathrm{K}-\mathrm{E}=$ eleocharoid; $\mathrm{K}-\mathrm{F}=$ fimbristyloid; $\mathrm{K}-\mathrm{R}=$ rhynchosporoid).

\begin{tabular}{|c|c|c|c|c|}
\hline $\begin{array}{l}\text { Tribes and genera (number of } \mathrm{C}_{3} \text { and } \mathrm{C}_{4} \\
\text { species) }\end{array}$ & $\begin{array}{c}\text { Kranz } \\
\text { type }\end{array}$ & $\begin{array}{l}\text { Biochemical } \\
\text { type }\end{array}$ & Habitat & Distribution \\
\hline \multicolumn{5}{|l|}{ Abildgaardieae } \\
\hline Abildgaardia $\left(1 \mathrm{C}_{3} / 16 \mathrm{C}_{4}\right)^{1,2,3,5,6}$ & $\mathrm{~K}-\mathrm{F}$ & NADP-ME & Dry field and distubed area & Tropical and subtropical \\
\hline Bulbostylis $\left(150 \mathrm{C}_{4}\right)^{1,2,3,4,5,6}$ & $\mathrm{~K}-\mathrm{F}$ & NADP-ME & Dry field, rare moist area & Tropical \\
\hline Crosslandia $\left(4 \mathrm{C}_{4}\right)^{2,4,6}$ & $\mathrm{~K}-\mathrm{F}$ & NADP-ME & Dunes and dry field & Tropical (Australia) \\
\hline Fimbristylis $\left(1 \mathrm{C}_{3} / 300 \mathrm{C}_{4}\right)^{1,2,3,4,5,6}$ & $\mathrm{~K}-\mathrm{F}$ & NADP-ME & Dry fields and distubed area & Tropical (Asia e Australia) \\
\hline Nelmesia $\left(1 \mathrm{C}_{4}\right)^{2,4,6}$ & $\mathrm{~K}-\mathrm{F}$ & NADP-ME & Field moist & Tropical (Africa) \\
\hline $\operatorname{Nemum}\left(10 \mathrm{C}_{4}\right)^{2,4,6}$ & $\mathrm{~K}-\mathrm{F}$ & NADP-ME & Field moist & Tropical (Africa) \\
\hline \multicolumn{5}{|l|}{ Cypereae } \\
\hline Alinula $\left(4 \mathrm{C}_{4} .\right)^{2,4,6}$ & $\mathrm{~K}-\mathrm{C}$ & NADP-ME & Field moist & Tropical (Africa) \\
\hline Ascolepis $\left(20 \mathrm{C}_{4}\right)^{2,4,6}$ & $\mathrm{~K}-\mathrm{C}$ & NADP-ME & Field moist & Tropical \\
\hline Cyperus subg. Cyperus $\left(260 \mathrm{C}_{4}\right)^{1,2,3,4,5,6}$ & $\mathrm{~K}-\mathrm{C}$ & NADP-ME & Field moist and distubed area & Tropical, rare subtropical \\
\hline Kyllinga $\left(75 \mathrm{C}_{4}\right)^{1,2,3,4,5,6}$ & $\mathrm{~K}-\mathrm{C}$ & NADP-ME & Field moist and distubed area & Tropical, rare subtropical \\
\hline Lipocarpha $\left(35 \mathrm{C}_{4}\right)^{2,4,6}$ & $\mathrm{~K}-\mathrm{C}$ & NADP-ME & Field moist & Tropical, rare subtropical \\
\hline Pycreus $\left(120 \mathrm{C}_{4}\right)^{1,2,3,4,5,6}$ & $\mathrm{~K}-\mathrm{C}$ & NADP-ME & Field moist and distubed area & Tropical \\
\hline Queenslandiela $\left(1 \mathrm{C}_{4}\right)^{2,4,5,6}$ & $\mathrm{~K}-\mathrm{C}$ & NADP-ME & Dunes & $\begin{array}{c}\text { Tropical (Africa, Asia and } \\
\text { Australia) }\end{array}$ \\
\hline Remirea $\left(1 \mathrm{C}_{4}\right)^{2,4,5,6}$ & $\mathrm{~K}-\mathrm{C}$ & NADP-ME & Dunes & Tropical \\
\hline Sphaerocyperus $\left(1 \mathrm{C}_{4}\right)^{2,4,5,6}$ & $\mathrm{~K}-\mathrm{C}$ & NADP-ME & Dry field & Tropical (Africa) \\
\hline Volkiella $\left(1 \mathrm{C}_{4}\right)^{2,3,4,5}$ & $\mathrm{~K}-\mathrm{C}$ & NADP-ME & Dunes & Tropical (Africa) \\
\hline \multicolumn{5}{|l|}{ Eleocharideae } \\
\hline Eleocharis $\left(244 \mathrm{C}_{3} / 8 \mathrm{C}_{4}\right)^{1,2,3,4,5,6,8}$ & $\begin{array}{c}\text { K-E; } \\
\text { K-C; } \\
\text { K-F }\end{array}$ & NAD-ME & Border of river and lakes & Tropical (America) \\
\hline \multicolumn{5}{|l|}{ Rhynchosporeae } \\
\hline $\begin{array}{l}\text { Rhynchospora grupo Capitatae } \\
\qquad\left(5 \mathrm{C}_{3} / 28 \mathrm{C}_{4}\right)^{1,2,3,4,5,7}\end{array}$ & $\begin{array}{l}\mathrm{K}-\mathrm{C} \\
\mathrm{K}-\mathrm{R}\end{array}$ & NADP-ME & Dry and moist fields & Neotropical \\
\hline
\end{tabular}

${ }^{1}$ Bruhl and Perry (1995), ${ }^{2}$ Bruhl and Wilson (2007), ${ }^{3}$ Bruhl et al. (1987), ${ }^{4}$ Goetghebeur (1998), ${ }^{5}$ Martins and Scatena (2011), ${ }^{6}$ Soros and Bruhl (2000), ${ }^{7}$ Ueno (2013), ${ }^{8}$ Martins and Scatena (2015).

Cypereae tribe - This tribe possesses 19 genera, 10 of which are Kranz species, including nine exclusively Kranz $\left(\mathrm{C}_{4}\right)$ species (Alinula, Ascolepis, Kyllinga, Lipocarpha, Pycreus, Queenslandiela, Remirea, Sphaerocyperus and Volkiella) and in Cyperus restricted to Cyperus subg. Cyperus (Tab. II). This tribe is monophyletic, and the Kranz taxa emerge in a separate clade from non-Kranz taxa (Fig. 2e). Cypereae present chlorocyperoid type
Kranz, characterized by two sheaths surrounding the vascular bundles: a continuous outer sheath (Os) and a discontinuous inner sheath (Is) in the major bundles (Fig. 2a). Both bundle sheaths develop from the procambium. The outer-sheath cells do not have chloroplasts (Fig. 2b), and the inner-sheath cells are generally centrifugal (Fig. $2 b)$, with inconspicuous grana and convoluted and contorted thylakoids (Fig. 2c-d). 

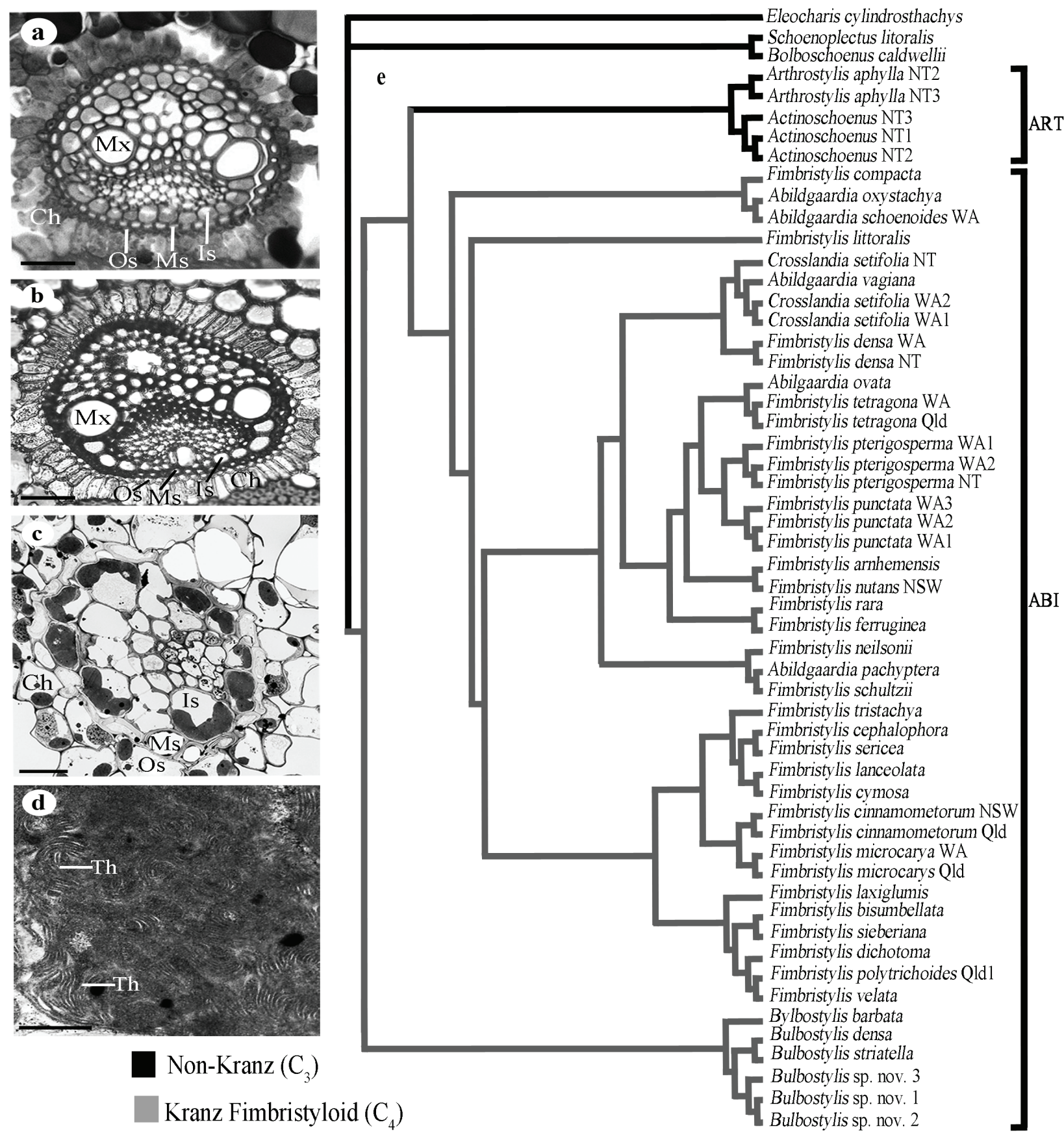

Figure 1 - Anatomical and ultrastructural features of the Kranz-fimbristyloid type and distribution of this type in the phylogeny of the Abildgaardieae and Arthrotylideae tribes. a-b. Bulbostylis scabra and Fimbristylis complanata, respectively - leaf in transverse section showing the vascular bundle. c-d. Fimbristylis autumnalis. c. Vascular bundle, highlighting centrifugal distribution of chloroplasts. d. Chloroplast of the inner bundle sheath cell with contorted and parelell thylakoids. e. Phylogeny of Abildgaardieae and Arthrotylideae tribes, adapted from Ghamkhar et al (2007). ART = Arthrostylideae; ABI = Abildgaardieae; $\mathrm{Ch}=$ chlorenchyma; Is = inner bundle sheath; $\mathrm{Ms}=$ middle bundle sheath; $\mathrm{Mx}=$ metaxylem; Os $=$ outer bundle sheath; $\mathrm{Th}=$ thylakoids. Bars: $(\mathbf{a}-\mathbf{b})=20$ $\mu \mathrm{m} ;(\mathbf{c})=10 \mu \mathrm{m},(\mathbf{d})=0.2 \mu \mathrm{m}$. For interpretation of the references to color in this figure, the reader is referred to the web version of this article. 

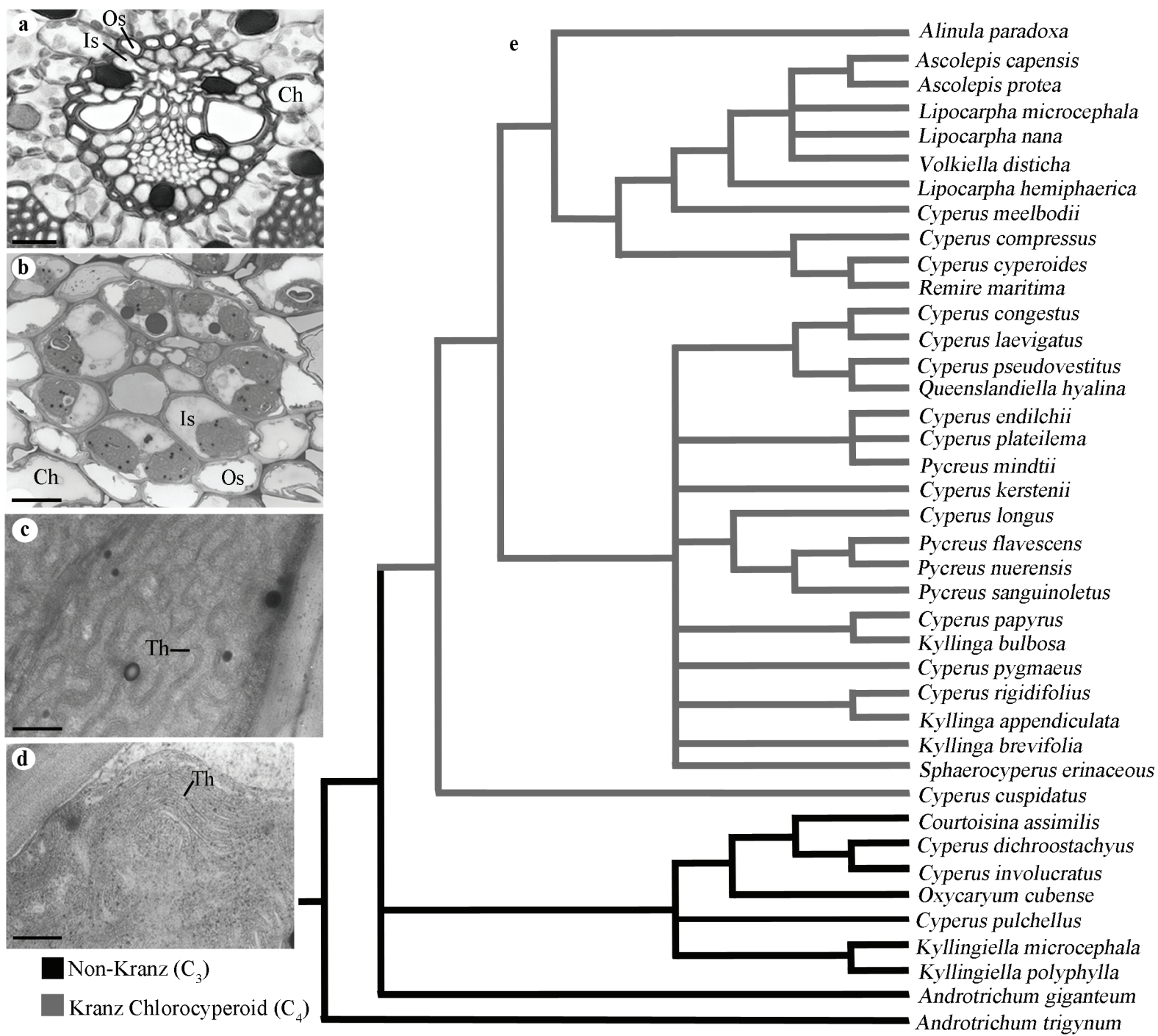

Figure 2 - Anatomical and ultrastructural features of the Kranz-chlorocyperoid type and distribution of this type in the phylogeny of the Cypereae tribe. a. Kyllinga brevifolia - leaf in transverse section showing the vascular bundle. b. Cyperus compressus - vascular bundle, highlighting centrifugal distribution of chloroplasts. c-d. Cyperus maritimus and C. ligularis, respectively chloroplast of the inner bundle sheath cell with convoluted and contorted thylakoids, respectively. e. Part of phylogeny of Cypereae tribe, detach to Kranz species, adapted from Muasya et al. (2008). $\mathrm{Ch}=$ chlorenchyma; Is = inner bundle sheath; Os = outer bundle sheath; $\mathrm{Th}=$ thylakoids. Bars: $(\mathbf{a})=20 \mu \mathrm{m} ;(\mathbf{b})=5 \mu \mathrm{m} ;(\mathbf{c}-\mathbf{d})=0.5 \mu \mathrm{m}$. For interpretation of the references to color in this figure, the reader is referred to the web version of this article.

Eleocharideae tribe - This tribe only includes the genus Eleocharis (250 spp.), presenting Kranz $\left(\mathrm{C}_{4}\right)$ and non-Kranz species $\left(\mathrm{C}_{3}\right)$ (Tab. II) and facultative $\mathrm{C}_{3} / \mathrm{C}_{4}$ and intermediate $\mathrm{C}_{3}-\mathrm{C}_{4}$ species. These species possess leaf lamina reduced to a tubular basal sheath, and the scape is the principal photosynthetic organ. The Kranz species of Eleocharis present eleocharoid, fimbristyloid and chlorocyperoid types (Fig. 3d-e). The eleocharoid type shows two continuous vascular bundle sheaths (Fig. 3a): an outer sheath (Os) without chloroplasts and an inner sheath (Is) with chloroplasts that do not show a constant location and have parallel thylakoids, occasionally forming grana (Fig. 3bc). The fimbristyloid and chlorocyperoid types in Eleocharis are anatomically similar to those previously described for Abildgaardieae and Cypereae. 


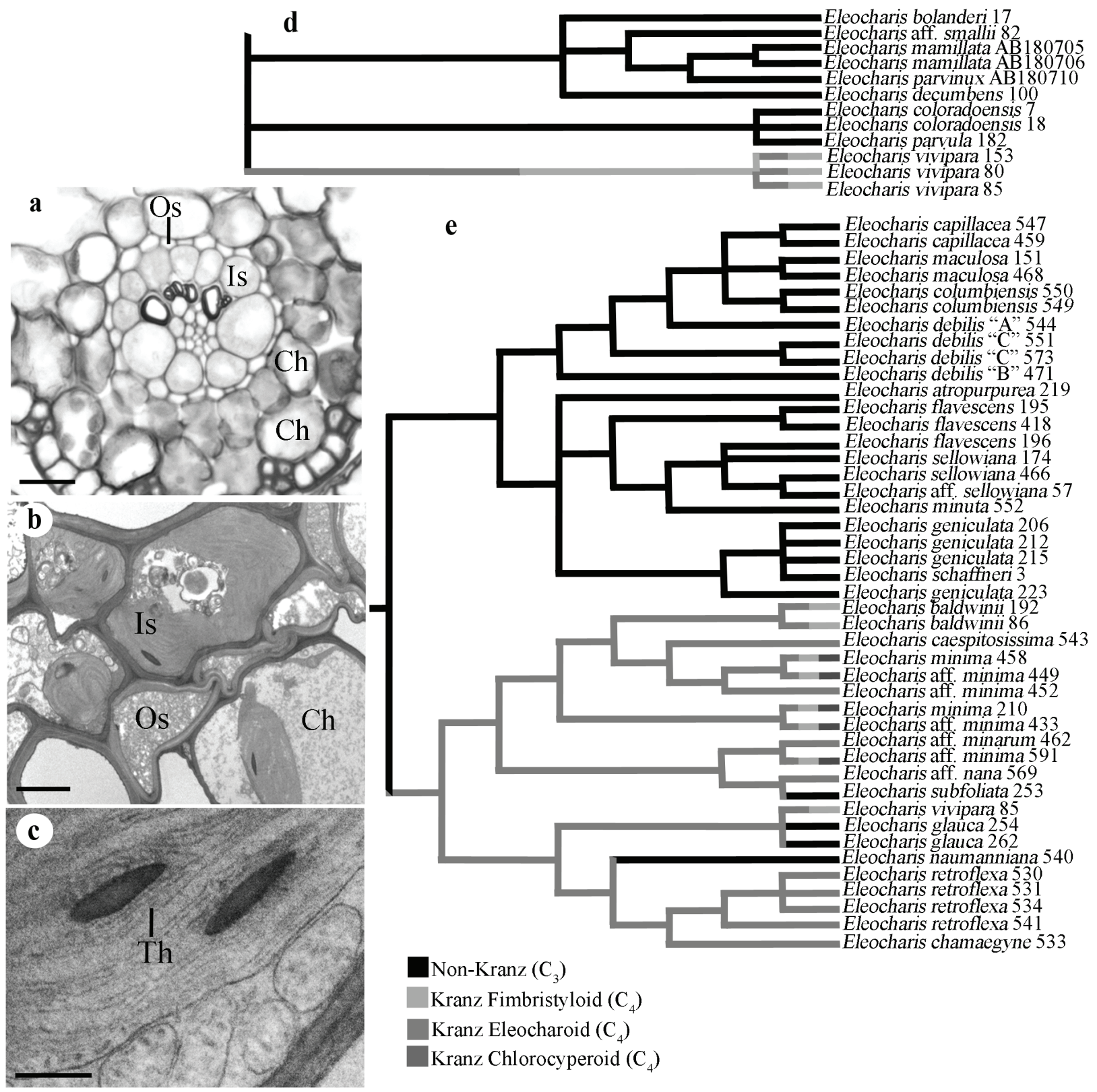

Figure 3 - Anatomical and ultrastructural features of the Kranz-eleocharoid type and distribution of this type in the phylogeny of the Eleocharideae tribe. a-c. Eleocharis minima. a. Scape in transverse section showing the vascular bundle. b. Vascular bundle, detach to chloroplast without Constant location in the inner bundle sheath. c. Chloroplast with parallel thylakoids in the inner bundle sheath. d-e. Part of phylogeny of the Rhynchosporeae tribe, highlighting the Kranz species, adapted from Roalson et al. (2010). $\mathrm{Ch}=$ chlorenchyma; Is = inner bundle sheath; Os = outer bundle sheath; Th = thylakoids. Bars: $(\mathbf{a})=20 \mu \mathrm{m} ;(\mathbf{b})=2 \mu \mathrm{m} ;(\mathbf{c})$ $=0.5 \mu \mathrm{m}$. For interpretation of the references to color in this figure, the reader is referred to the web version of this article.

Rhynchosporeae tribe - This tribe possesses two genera, Pleurostachys and Rhynchospora, and only Rhynchospora has species with Kranz anatomy $\left(\mathrm{C}_{4}\right)$ restricted to Pauciflorae (Pau) and Pluriflorea (Plu) sections from the Capitatae group
(Tab. II). This species presents chlorocyperoid and the rhynchosporoid Kranz types that occur in distinct clades in the phylogenetic analysis (Fig. 4e). The chlorocyperoid has two sheaths surrounding the vascular bundles, wherein the outer $(\mathrm{Os})$ is 
continuous and the inner (Is) is discontinuous in the major bundles (Fig. 4a). Similar to the chlorocyperoid type in Cypereae, both sheaths (outer and inner) originate from the procambium. The chloroplasts are absent in the outer sheath cells (Os), whereas these organelles are centrifugal or without pattern, with convoluted and parallel thylakoids in the inner sheath cells (Fig. 4b). The rhynchosporoid present a unique continuous bundle sheath (Ss - single sheath) (Fig. 4c), originating from the procambium and presenting cells with chloroplasts located centrifugally or without pattern, with inconspicuous grana and parallel thylakoids (Fig. 4d).

\section{DISCUSSION}

The data obtained from the present study and previously published studies suggest that multiple origins of Kranz anatomy occurred in Cyperaceae due to different environmental factors that promote photorespiration. The Kranz anatomy is uniform in Abildgaardieae Cypereae tribes, showing only one anatomical type, and varied in Rhynchosporeae and Eleocharideae tribes, showing more than one type.

In Abildgaardieae, the Kranz anatomy $\left(\mathrm{C}_{4}\right)$ likely had only one origin, before the occurrence of a single anatomical (fimbristyloid) and biochemical (NADP-ME) type, with possible reversion to the $\mathrm{C}_{3}$ pathway (not Kranz) in Abildgaardia hygrophila, Fimbristylis variegata and representatives of the Arthrostylideae tribe. This hypothesis is confirmed by phylogenomic and phylogenetic studies (Besnard et al. 2009, Ghamkhar et al. 2007), suggesting the initial onset of $\mathrm{C}_{4}$ photosynthesis in Bulbostylis (ca. $19.6 \pm 4.9 \mathrm{Ma}$ ), followed by Fimbristylis (ca. 12.3 $\pm 3.8 \mathrm{Ma}$ ). Moreover, the species of Abildgaardieae is primarily observed in xeric environments (open fields, rocky outcrops, dunes), and the $\mathrm{C}_{4}$ pathway must have arisen in this environment, where this biochemical pathway is more advantageous (Sage 2004, Sage et al. 2012).
In the Cypereae tribe, the Kranz anatomy likely derived from a single source, as the Kranz species in this tribe emerged in the same clade (Muasya et al. 2002, 2009) and have the same anatomical (chlorocyperoid) and biochemical (NADPME) types and similarities in the structure of the chloroplasts. The emergence of $\mathrm{C}_{4}$ in this tribe is indicated ca. 10.9 $\pm 3.8 \mathrm{Ma}$ (Besnard et al. 2009), initially in mesophyte species (with $\mathrm{C}_{3}$ mesophytes ancestors) and subsequently in xerophytes (with $\mathrm{C}_{4}$ mesophytes ancestors), as most of the $\mathrm{C}_{4}$ species primarily occur in mesic environments and a minority of these species are observed in xeric areas. This hypothesis has also been postulated for the $\mathrm{C}_{4}$ species of Poaceae (Osborne and Freckleton 2009). The occurrence of $C_{4}$ metabolism in mesic environments with high water availability is associated with the high density, high temperature and increased luminosity, which reduce the absorption of $\mathrm{CO}_{2}$ and carbohydrate production in plants (Bowes et al 200, Sage et al. 2012).

The plasticity of the $\mathrm{C}_{4}$ pathway makes it difficult to interpret the origin of this pathway in Eleocharideae, with the possibility of two sources with reversals for $\mathrm{C}_{3}$ or multiple origins. The Kranz types in this tribe vary between individuals of the same species (Ueno 1996, 2004, Murphy et al. 2007) and even in the same individual (Martins and Scatena 2015). As eleocharoid types are considered more related to $\mathrm{C}_{4}$ metabolism, and the fimbristyloid types are considered $\mathrm{C}_{3}-\mathrm{C}_{4}$ intermediates (Murphy et al. 2007), it is likely that the aquatic environment of these plants promotes anatomical plasticity, such as the number of vascular bundles and the presence and development of aerenchyma (Martins and Scatena 2015), as observed in other anatomical structures.

Structurally, the difference between the eleocharoid and fimbristyloid types is the size and shape of the cells of the inner layer chlorenchyma (Ch) (both originate from the ground meristem), which is slightly larger and elongated in the first 

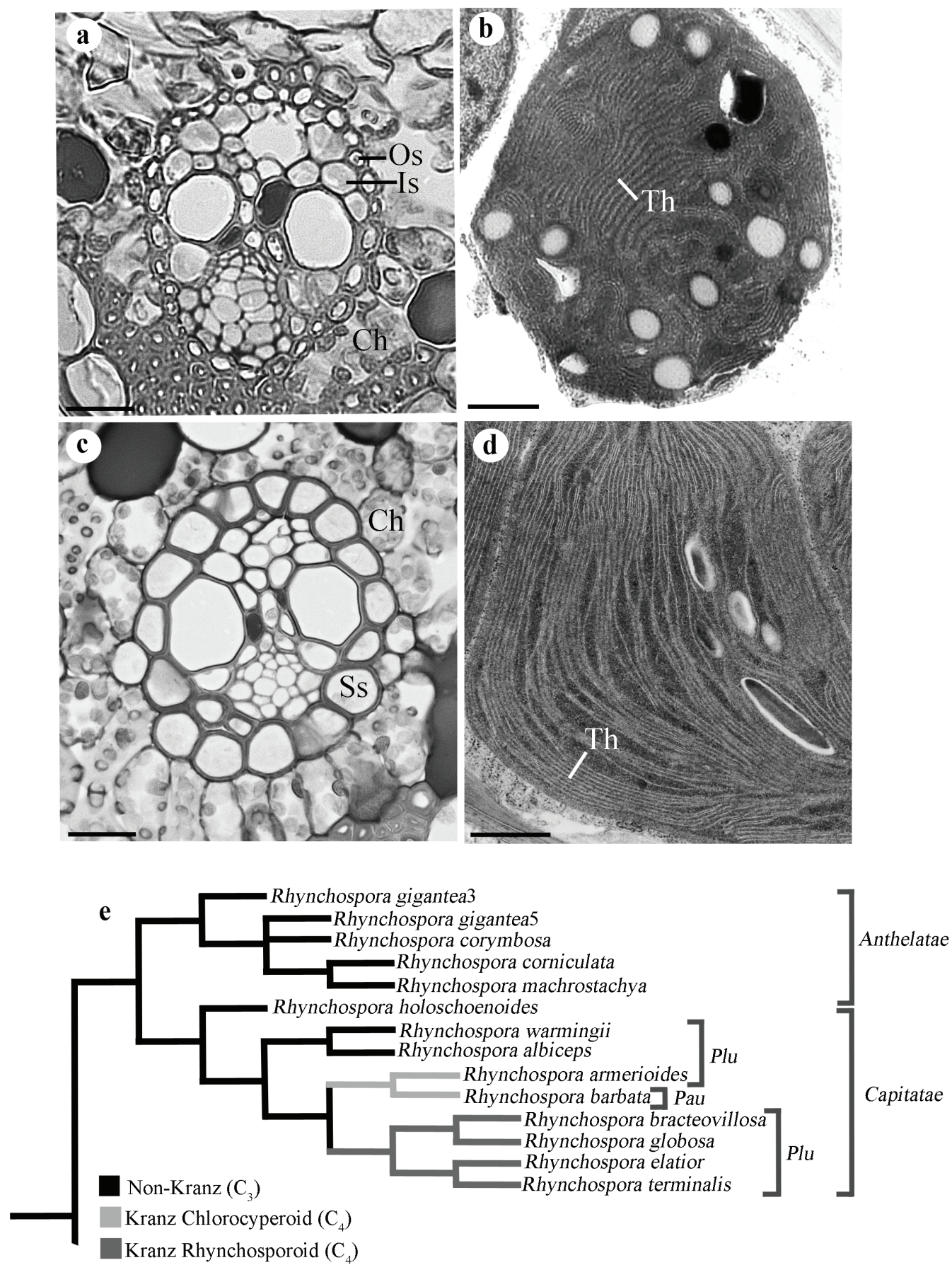

Figure 4 - Anatomical and ultrastructural features of the Kranz-chlorocyperoid and Kranz-rhynchosporoid types and distribution of these types in the phylogeny of the Rhynchosporeae tribe. a-b. Rhynchospora barbata. a. Leaf in transverse section showing the vascular bundle. b. Chloroplast of the inner bundle sheath cell with parallel thylakoids. c-d. Rhynchospora globosa. c. Leaf in transverse section showing the vascular bundle. d. Chloroplast of the inner bundle sheath cell with parallel thylakoids. e. Part of phylogeny of Rhynchosporeae tribe, detach to Kranz species, adapted from Thomas et al. (2008). Ch = chlorenchyma; Is = inner bundle sheath; Os = outer bundle sheath; $\mathrm{Pau}=$ Pauciflorae; $\mathrm{Plu}=$ Pluriflorae; $\mathrm{Ss}=$ single bundle sheath; $\mathrm{Th}=$ thylakoids. Bars: $(\mathbf{a}, \mathbf{c})=20 \mu \mathrm{m} ;(\mathbf{b}, \mathbf{d})=0.5 \mu \mathrm{m}$. For interpretation of the references to color in this figure, the reader is referred to the web version of this article. 
type, and rounded and smaller in the second type. These types also differ in the continuity of the inner sheath in the major vascular bundles, being continuous only in the eleocharoid type (Soros and Bruhl 2000). However, the continuity of the inner sheath might vary along the scape and can be interrupted in the apical region, as indicated for Eleocharis minima (Martins and Scatena 2015), described as Kranz eleocharoid (Murphy et al. 2007, Martins and Scatena 2011).

In Eleocharideae, the $\mathrm{C}_{4}$ pathway is considered intermediate to recent (Eleocharis vivipara - ca. $10.5 \pm 3.2 \mathrm{Ma}$; E. baldwinii $-4.4 \pm 2.1 \mathrm{Ma}$ ) compared with the other $\mathrm{C}_{4}$ species of this family (Besnard et al. 2009). These authors indicated that Cyperaceae species with different Kranz types do not present significant genetic modifications. Thus, before the plasticity observed in Eleocharis, the changing of $\mathrm{C}_{3}$ to $\mathrm{C}_{4}$ metabolism might have required a small number of genetic modifications, as indicated by Christin et al. (2007) for groups with high plasticity in present $\mathrm{C}_{4}$ photosynthesis. Plasticity in Kranz anatomy was also observed in other $\mathrm{C}_{4}$ groups, such as some species of Poaceae and Asteraceae (Araus et al. 1990, Gong et al. 2011).

In Rhynchosporeae, it is likely that the Kranz anatomy arose twice, once for each anatomical type, as chlorocyperoid and rhynchosporoid occur in distinct clades (Thomas et al. 2008). Both Kranz types occur in Pauciflorae and Pluriflorae sections (Ueno and Koyama 1987), and although these types differ in the number of sheaths and chloroplast locations, similarities are observed in chloroplast distribution and thylakoid organization. Genetic markers indicate that the $\mathrm{C}_{4}$ pathway is recent in Rhynchospora (ca. $7.4 \pm 2.8 \mathrm{Ma}$ ) compared with the other species of this family (Besnard et al. 2009), and phylogenetic data show the occurrence of the $\mathrm{C}_{4}$ pathway in derivative gender groups (Thomas et al. 2008). The Kranz $\left(\mathrm{C}_{4}\right)$ of the Rhynchospora species are primarily Neotropical, occurring in xeric environments, such as open fields and savannas
(Ueno and Koyama 1987), living sympatrically with non-Kranz $\left(\mathrm{C}_{3}\right)$ species of the same genus. Thus, it has been suggested that the $\mathrm{C}_{4}$ pathway arose in some lineages of the genus as an adaptation to conditions of water stress, high temperatures and light from $\mathrm{C}_{3}$ ancestors potentially occurring in this type of environment. However, the occurrence of different Kranz types in closer phylogenetic groups living sympatrically is intriguing and requires more detailed studies.

The variations among the Kranz types in Cyperaceae reflect essential differences in the structure, not the origin, of the tissues. The homologous chlorophyllian cells surrounding the vascular bundles arise from the ground meristem and might have an elongated (chlorophyll parenchyma) or rounded (outer sheath) shape. In chlorocyperoid, eleocharoid and fimbristyloid types, the procambium gives rise to two vascular sheaths, with chloroplasts only in the inner sheath. In the rhynchosporoid type, only one sheath has procambial origin and presents chloroplasts. This sheath is homologous to the outer sheath, which lacks chloroplasts with procambial origin.

Herein, we showed the multiple origins of Kranz anatomy in Cyperaceae in different phylogenetic groups, confirming the results of Soros and Bruhl (2000), Muasya et al. (2002, 2008, 2009), Ghamkhar et al. (2007), Thomas et al. (2008) and Roalson et al. (2010). Thus, this study represents adaptive convergence, as phylogenetic relationships are not reflected. In addition, the anatomical types are not associated with specific environmental conditions because the Kranz species of Abildgaardieae, Rhynchospora and some of Cypereae occur in similar xeric environments or even live sympatrically and present different Kranz types. In addition, Eleocharis representatives vary in relation to the occurrence and the type of Kranz anatomy in individuals of the same species.

Thus, the Kranz types in Cyperaceae likely result from ecological pressures that promote 
photorespiration, even in different environmental conditions. The Kranz species of Abildgaardieae and Rhynchosporeae tribes are xerophytes, whereas the Cypereae species are mesophytes or xerophytes and the Eleocharideae species are hydrophytes. Thus, independent of the environment, distinct lineages of Cyperaceae have similar evolutionary pathways for more efficient photosynthesis.

\section{ACKNOWLEDGMENTS}

We thank the Fundação de Amparo à Pesquisa do Estado de São Paulo (FAPESP) for a PhD grant (2008/09380-2) to S. Martins and financial support (2011/18275-0) and the Conselho Nacional de Desenvolvimento Científico e Tecnológico (CNPq) for financial support to V.L. Scatena (301692/20106 and 471837/2011-3) and to S.R. Machado (2008/301464-1) and the Centre of Microscopy of the Universidade Estadual Paulista (Botucatu).

\section{RESUMO}

Cyperaceae é uma das famílias de angiospermas com maior diversidade de espécies com anatomia Kranz. Para a família foram descritos quatro diferentes tipos de anatomia Kranz (clorociperoide, eleocaroide, fimbristiloide e rincosporoide) e a ocorrência e as características estruturais desses tipos são importantes para traçar hipóteses evolutivas. Este trabalho visou examinar dados disponíveis sobre anatomia Kranz de Cyperaceae com ênfase na taxonomia, distribuição geográfica, habitat e anatomia para inferir a possível origem da anatomia Kranz na família. Verificou-se que os quatro tipos de anatomia Kranz (relacionada à fotossíntese $\mathrm{C}_{4}$ ) em Cyperaceae surgiram diversas vezes em grupos não relacionados filogeneticamente. Por outro lado, observou-se a convergência desses tipos anatômicos, exceto o rincosporoide, em determinados grupos. Assim, a origem diversa dessas espécies pode ser resultado de diferentes pressões ambientais que promovem a fotorrespiração. Maior variação da ocorrência da anatomia Kranz e de tipos anatômicos foi observada em Eleocharis, cujo surgimento da via $\mathrm{C}_{4}$ é recente quando comparado aos demais gêneros da família e as espécies deste gênero vivem em ambientes aquáticos.

Palavras-chave: anatomia, ultraestrutura, taxonomia, filogenia, Cyperaceae.

\section{REFERENCES}

ARAUS JL, BROWN RH, BOUTON JH AND SERRET MD. 1990. Leaf anatomical characteristics in Flaveria trinervia $\left(\mathrm{C}_{4}\right)$, Flaveria brownii $\left(\mathrm{C}_{4}\right.$-like $)$ and their $\mathrm{F} 1$ hybrid. Photosynth Res 26: 49-57.

BESNARD G, MUASYA AM, RUSSIER F, ROALSON NS AND CHRISTIN PA. 2009. Phylogenomics of $\mathrm{C}_{4}$ photosynthesis in sedges (Cyperaceae): Multiple appearances and genetic convergence. Mol Biol Evol 26: 1909-1919.

BOWES G, RAO SK, ESTAVILLO GM AND REISKIND JB. 2002. $\mathrm{C}_{4}$ mechanisms in aquatic angiosperms: comparisons with terrestrial $\mathrm{C}_{4}$ system. Func Plant Biol 29: 379-392.

BRUHL JJ. 1995. Sedge genera of the world: relationships and new classification of the Cyperaceae. Aust Syst Bot 8: 125-305.

BRUHL JJ AND PERRY S. 1995. Photosynthetic pathwayrelated ultrastructure of $\mathrm{C}_{3}, \mathrm{C}_{4}$ and $\mathrm{C}_{3}-\mathrm{C}_{4}$ intermediate sedge (Cyperaceae), with special reference to Eleocharis. Aust J Plant Physio 22: 521-530.

Bruhl JJ, Stone NE AND Hattersley PW. 1987. C $_{4}$ acid decarboxylation enzymes and anatomy in sedges (Cyperaceae): first record of NAD-malic enzyme species. Aust J Plant Physio 22: 521-530.

BRUHL JJ AND WILSON KL. 2007. Towards a comprehensive survey of $\mathrm{C}_{3}$ and $\mathrm{C}_{4}$ photosynthetic pathway in Cyperaceae. In: Columbus JT, Friar EA, Hamilton CW, Porter JM, Prince LM and Simpson MG (Eds), Monocots: comparative biology and evolution, Claremont: Rancho Santa Ana Botanic Garden, p. 99-148.

CAROLIN RC, JACOBS SWL AND VESK M. 1977. The ultrastructure of Kranz cells in the family Cyperaceae. Bot Gaz 138: 413-419.

Christin PA, SALAmin N, SAVOlainen V, DUVAll MR AND BESNARD G. 2007. C 4 photosynthesis evolved in grasses via parallel adaptive genetic changes. Curr Biol 17: 1241-1247.

FEDER N AND O'BRIEN TP. 1968. Plant microtechnique: some principles and new methods. Am J Bot 55: 123-142.

GHAMKHAR K, MARCHANT AD, WILSON KL AND BRUHL JJ. 2007. Phylogeny of Abildgaardieae (Cyperaceae) inferred from ITS and trnL-F data. Aliso 23: 149-164.

GoetgheBeur P. 1998. Cyperaceae. In: Kubitzki K, Huber H, Rudall PJ, Stevens PS and Stützel T (Eds), The families and genera of vascular plants. Berlin: Springer-Verlag, $\mathrm{p}$. 141-190.

GONG CM, BAi J, DENG JM, WANG GX AND LIU XP. 2011. Leaf anatomy and photosynthetic carbon metabolic 
characteristics in Phragmites communis in different soil water availability. Plant Ecol 211: 675-687.

HABERLANDT GFJ. 1914. Physiological plant anatomy. London, MacMillan.

JOHANSEN D. 1940. Plant microtechnique. New York, McGraw-Hill Book Co. Inc.

LUNDGREN MR, OSBORNE CP AND CHRISTIN PA. 2014. Deconstructing Kranz anatomy to understand $\mathrm{C}_{4}$ evolution. J Exp Bot 65: 3357-3369.

MACHADO SR AND RODRIGUES TM. 2004. Anatomia e ultraestrutura do pulvino primário de Pterodon pubescens Benth. (Fabaceae-Faboideae). Rev Bras Bot 27: 135-147.

MARTINS S AND ALVES M. 2009. Anatomical features of species of Cyperaceae from northeastern Brazil. Brittonia 61: 189-200.

MARTINS S AND SCATENA VL. 2011. Bundle sheath ontogeny in Kranz and non-Kranz species of Cyperaceae (Poales). Aust J Bot 59: 554-562.

MARTINS S, MACHADO SR AND SCATENA VL. 2015. An overview about ultrastructure of Kranz anatomy in Cyperaceae (Poales). Rodriguésia 66: 633-643.

MARTINS S AND SCATENA VL. 2015. Anatomical variations in scapes of Eleocharis minima Kunth (Cyperaceae, Poales) - amphibian and Kranz species. Rodriguésia 66: 627-631.

MuAsya AM, Simpson DA AND ChASE MW. 2002. Phylogenetic relationships in Cyperus L. s.l. (Cyperaceae) inferred from plastid DNA sequence data. Bot J Linn Soc 138: 145-153.

MUASYA AM, SIMPSON DA, VERBOOM GA, GOETGHEBEUR P, NACZI RFC, CHASE MW AND SMETS E. 2008. Phylogeny of Cyperaceae based on DNA sequence data: Current progress and future prospects. Bot Rev 75: 2-21.

Muasya AM, VRiJdaghs A, Simpson DA, Chase MW, GOETGHEBEUR P AND SMETS E. 2009. What is a genus in Cypereae: phylogeny, character homology assessment and generic circumscription in Cypereae. Bot Rev 75: 52-66.

MURPHY LR, BARROCA J, FRANCESCHI VR, LEE R, ROALSON EH, EDWARDS GE AND KU MSB. 2007. Diversity and plasticity of $\mathrm{C}_{4}$ photosynthesis in Eleocharis (Cyperaceae). Func Plant Biol 34: 571-580.

OSBORNE CP AND FRECKLETON RP. 2009. Ecological selection pressures for $\mathrm{C}_{4}$ photosynthesis in the grasses. Proc Roy Soc Lond B Biol Sci 276: 1753-1760.
REYNOLDS ES. 1963. The use of lead citrate at high $\mathrm{pH}$ as an electron-opaque stain in electron microscopy. J Cell Biol 17: 208-212.

RoAlson EH, HiNCHLIFF CE, TREVISAN R AND SILVA CRM. 2010. Phylogenetic relationships in Eleocharis (Cyperaceae): $\mathrm{C}_{4}$ Photosynthesis origins and patterns of diversification in the spikerushes. Syst Bot 35: 257-271.

SAGE RF. 2004. The evolution of $\mathrm{C}_{4}$ photosynthesis. New Phytologist 161: 341-370.

SAGE RF, SAGE TL AND KOCACINAR F. 2012. Photorespiration and the evolution of $\mathrm{C}_{4}$ photosynthesis. Ann Rev Plant Biol 63: 19-47.

SOROS CL AND BRUHL JJ. 2000. Multiple evolutionary origins of $\mathrm{C}_{4}$ photosynthesis in the Cyperaceae. In: Wilson KL and Morrison DA (Eds), Monocots: systematics and evolution. Melbourne: CSIRO Publishing, p. 629-636.

SOROS CL AND DENGLER NG. 2001. Ontogenetic derivation and cell differentiation in photosynthetic tissues of $\mathrm{C}_{3}$ and $\mathrm{C}_{4}$ Cyperaceae. Am J Bot 88: 992-1005.

TAKEDA T, UENO O, SAMEJIMA M AND OHTANI T. 1985. An investigation for the occurrence of $\mathrm{C}_{4}$ photosynthesis in the Cyperaceae from Australia. Bot Mag Tokyo 98: 393-411.

THOMAS T, ARAÚJO AC AND ALVES MV. 2008. A preliminary molecular phylogeny of the Rhynchosporeae (Cyperaceae). Bot Rev 75: 22-29.

UENO O. 1996. Structural characterization of photosynthetic cells in an amphibious sedge, Eleocharis vivipara, in relation to $\mathrm{C}_{3}$ and $\mathrm{C}_{4}$ metabolism. Planta 199: 382-393.

UENO O. 2004. Environmental regulation of $\mathrm{C}_{3}$ and $\mathrm{C}_{4}$ differentiation in the amphibious sedge, Eleocharis baldwinii and comparisons with related species. Plant Cell Environ 27: 627-639.

UENO O. 2013. Ultrastructure and carbon isotope ratios of leaves in $\mathrm{C}_{4}$ species of Rhynchospora (Cyperaceae) that differ in the location of Kranz cells. Int J Plant Sci 174: 702-709.

UENO O AND KoyAma T. 1987. Distribution and evolution of $\mathrm{C}_{4}$ syndrome in Rhynchospora (RhynchosporeaeCyperaceae). Bot Mag Tokyo 100: 63-85.

UENO O AND SAMEJINA M. 1989. Structural features of NADmalic enzyme type $\mathrm{C}_{4}$ Eleocharis: An additional report of $\mathrm{C}_{4}$ acid decarboxylation types of the Cyperaceae. Bot Mag Tokyo 102: 393-402. 